\title{
STRATEGI PADEPOKAN KARAKTER DALAM MEMPERKUAT KARAKTER BERPIKIR KRITIS PADA WARGA NEGARA MUDA ABAD
}

21

\author{
Sutiyono ${ }^{1}$, Danang Prasetyo ${ }^{2}$ \\ ${ }^{1}$ MKWU PPKn Universitas Putera Batam, ${ }^{2}$ MKWU PPKn STIPRAM \\ Ambarrukmo Yogyakarta \\ pb11707@puterabatam.ac.id; danang.ppsuny@gmail.com
}

\begin{abstract}
Abstrak: Universitas Negeri Semarang sebagai lembaga pendidikan tinggi memiliki tanggung jawab menciptakan lulusan yang berkarakter. Inovasi yang dilakukan oleh Universitas Negeri Semarang adalah menciptakan Padepokan Karakter yang merupakan inovasi di bidang pendidikan karakter. Salah satu focus Padepokan Karakter adalah mengembangkan model pembelajaran berbasis nilai untuk menguatkan berpikir kritis mahasiswa. Penelitian ini bertujuan untuk mengidentifikasi secara kualitatif strategi Padepokan Karakter Universitas Negeri Semarang dengan model pembelajaran berbasis bursa nilai sebagai upaya menguatkan karakter berpikir kritis mahasiswa di abad 21. Penelitian ini menggunakan pendekatan kualitatif dengan metode fenomenologi. Penelitian ini dilakukan di Padepokan Karakter Universitas Negeri Semarang. Pengumpulan data menggunakan teknik dokumentasi, observasi, dan wawancara. Analisis data menggunakan model interaktif dari Miles dan Huberman. Hasil penelitian menunjukkan bahwa Padepokan Karakter yang dibentuk oleh Universitas Negeri Semarang telah mampu memperkuat karakter mahasiswa, terutama dalam kakakter berpikir kritis. Metode yang dikembangkan dalam Padepokan Karakter tersebut yaitu model pembelajaran berbasis bursa nilai. Hasil penelitian ini mendukung teori tentang berpikir kritis yang mencakup kemampuan menganalisis, mengevaluasi, menilai, dan memecahkan suatu masalah.
\end{abstract}

Kata kunci: strategi Padepokan Karakter, berpikir kritis, warga negara muda.

\section{THE STRATEGY OF PADEPOKAN KARAKTER IN STRENGTEN CRITICAL THINKING CHARACTER ON YOUNG CITIZENS IN THE $21^{\text {ST }}$ CENTURY}

\begin{abstract}
Universitas Negeri Semarang as an institution of higher education has the responsibility of creating graduates with noble character. The innovation undertaken by Universitas Negeri Semarang is creating Padepokan Karakter which is an innovation in the field of character education. One focus of Padepokan Karakter is developing value-based learning models to strengthen students' critical thinking. This study aims to qualitatively identify the strategy of Padepokan Karakter in Universitas Negeri Semarang with a value exchangebased learning model as an effort to strengthen the character of students' critical thinking in the 21 st century. This study uses a qualitative approach with a phenomenological method. This research was conducted at Padepokan Karakter in Universitas Negeri Semarang. Data collection uses documentation, observation,
\end{abstract}


and interview techniques. Data analysis uses interactive models of Miles and Huberman. The results showed that the Padepokan Karakter formed by Universitas Negeri Semarang has been able to strengthen the character of students, especially in critical thinking. The method developed in the Padepokan Karakter is a value-based learning model. The results of this study support the theory of critical thinking that includes the ability to analyze, evaluate, assess, and solve a problem.

Keywords: strategy of Padepokan Karakter, critical thinking, young citizens.

\section{PENDAHULUAN}

Kajian tentang karakter dan pendidikan karakter merupakan persoalan yang tidak ada habisnya hingga saat ini. Karakter selalu saja menjadi topik menarik untuk dibahas di era kapan pun (lintas zaman) (Putri \& Ramadhani, 2018). Hal ini disebabkan karena sifat karakter yang melekat pada manusia berkembang secara dinamis. Penyebab kedinamisan karakter manusia bisa berasal dari dalam dirinya (intern factor) dan dari luar manusia itu sendiri (external factor).

Penyebab dari dalam (intern factor) bisa berasal dari pengetahuan manusia yang beragam. Terkait dengan pengetahuan (knowledge), setiap orang memiliki tingkat kemampuan berpikir yang cenderung berbeda walaupun pada satu kelompok yang sama. Sedangkan, pengaruh dari luar (external factor) bisa berasal dari lingkungan masyarakat, pendidikan, bahkan tayangan dari media massa melalui teknologi modern. Hal inilah, kemudian menjadikan kemampuan berpikir kritis sebagai sebuah karakter yang penting bagi diri manusia.

Banks (2008: 37) menyatakan bahwa era globalisasi ini merupakan keniscayaan yang harus dihadapi oleh semua bangsa di dunia. Ditambah lagi dengan kemunculan teknologi yang canggih semakin memperlancar perkembangan proses globalisasi yang memiliki prinsip adanya interdependensi antara masyarakat di satu negara dan negara lainnya. Di era global sekarang ini terdapat budaya yang berfungsi sebagai sentral dalam menentukan sistem, yang biasa disebut sebagai the one, dan ada yang dimaksud sebagai the others atau budaya pinggiran, termasuk dalam negara yang secara tidak langsung dikendalikan (Abidin, 2000: 186).

Saat ini Indonesia memiliki kurang lebih 50\% warga negara yang disebut generasi milenial. Generasi ini masuk dalam kategori usia produktif, yang diprediksi pada tahun 2020 sampai dengan tahun 2030 jumlahnya akan mencapai 70\%. Peristiwa ini akan menjadi momentum kebangkitan negara Indonesia menghadapi era global yang sudah masuk ke semua sistem kehidupan di tengah masyarakat (Lalo, 2018: 74). Akan tetapi era global juga membawa dampak buruk pada perilaku generasi milenial tersebut. Akibat kebebasan teknologi dalam mengakses konten atau isi, dapat mengakibatkan pergeseran budaya asli bangsa ke arah yang kurang tepat atau disebut sebagai akulturasi budaya. Persoalan ini dengan mudah akan mempengaruhi perilaku generasi muda sebagai manusia yang sedang berkembang. Sebagaimana yang dilansir oleh Sexual Behavior Survey 2011 melalui survey yang dilakukan di lima kota besar di Indonesia, 
yaitu Jabodetabek (Jakarta, Bogor, Depok, Tangerang, Bekasi), Bandung, Yogyakarta, Surabaya, dan Bali, ditemukan data bahwa dari 663 responden, secara langsung mengaku bahwa 39\% responden yang berumur sekitar 15-19 tahun pernah berhubungan seksual, dan begitu juga sisanya, $61 \%$ yang berusia 20 25 tahun. Lebih memprihatinkan lagi dilihat dari profesi, yang ternyata peringkat tertinggi yang pernah melakukan free sex adalah kalangan mahasiswa, yakni $31 \%$, disusul karyawan kantor $18 \%$, sedang sisanya $6 \%$ siswa SMP dan SMA. Beberapa kasus tersebut menunjukkan bahwa pendidikan yang dilakukan di lembaga-lembaga pendidikan di Indonesia belum optimal untuk penguatan karakter bangsa (Detik.com, 2011).

Saat ini, krisis karakter kebangsaan semakin mewabah terjadi pada generasi muda yang semakin melahirkan keprihatinan demi keprihatinan. Hampir setiap hari media massa memberitakan kasus kejahatan, pembunuhan, perkelahian, tawuran, meningkatnya pergaulan bebas, maraknya angka kekerasan remaja (Setiawati, 2017:350).

Sebagai langkah mengatasi masalah tersebut, perlu persiapan yang diberikan negara kepada generasi milenial dalam menghadapi era globalisasi. Salah satunya dengan cara menjalankan program pendidikan karakter yang terpola dan terukur (Lalo, 2018: 74) Hal ini perlu dilakukan mengingat pentingnya cakupan pembinaan karakter bangsa dalam rangka menjaga identitas karakter bangsa dari pengaruh arus globalisasi (Setiawati, 2017: 351). Karakter bangsa inilah yang nantinya menjadi pilar akhlak yang dimiliki diri generasi muda sehingga mampu menjadi sosok warga negara yang berkarakter baik (good character (Budiwibowo, 2013: 48).

Salah satu sektor yang dapat mendidik warga negara muda yaitu lembaga pendidikan formal, seperti yang dilakukan oleh Universitas Negeri Semarang (UNNES). Sebagai salah satu lembaga pendidikan dan tenaga kependidikan (LPTK), Universitas Negeri Semarang memiliki sebuah lembaga otonom khusus untuk mendidik mahasiswa supaya memiliki kemampuan berpikir kritis sebagai kompetensi menghadapi degradasi karakter. Berpikir kritis adalah kemampuan untuk menganalisis, mengevaluasi, menilai, dan memecahkan masalah (Philips, 2010).

Inovasi ini sesuai dengan keterampilan yang diperlukan pada abad 21 yaitu keterampilan berinovasi dalam pembelajaran, literasi digital, dan keterampilan hidup dan karir (Trilling \& Fadel, 2009: 68). Inovasi pembelajaran diwadahi dalam tempat yang disebut sebagai "Padepokan Karakter" di Universitas Negeri Semarang. Salah satu karakter yang dikembangkan di Padepokan Karakter tersebut yaitu berpikir kritis. Kecerdasan berpikir menurut hasil penelitian Subekti (2009: 42) dapat dijabarkan menjadi tujuh karakter yang membentuk kata SUCCESS, yaitu sensorial, understanding, control, cognitive, exact, supple, dan silly. Strategi ini dapat dijadikan sebagai salah satu alternatif untuk penguatan karakter di kalangan mahasiswa sebagai warga negara muda khususnya di Universitas Negeri Semarang.

Begitu pentingnya keberadaan Padepokan Karakter dengan model pembelajaran yang dikembangkannya. Namun, keberadaan Padepokan Karakter ini belum banyak diketahui oleh kebanyakan pendidik. Belum ada kajian khusus yang mengungkap Padepokan Karakter di Universitas Negeri Semarang ini terkait dengan penguatan pendidikan karakter mahasiswa. Oleh karena itu, penelitian tentang penguatan karakter di Padepokan Karakter menjadi penting, terutama untuk memberikan informasi yang berharga tentang alternatif model pendidikan karakter di kalangan warga negara muda di Indonesia. 


\section{METODE}

Penelitian ini menggunakan pendekatan kualitatif dengan metode fenomenologi (Creswell, 1998: 91). Penelitian ini dilakukan di Padepokan Karakter yang berada di Universitas Negeri Semarang, Kota Semarang, Jawa Tengah. Penelitian dilakukan pada bulan Desember 2018 sampai bulan April 2019.

Pengumpulan data dalam penelitian ini menggunakan teknik dokumentasi, observasi, dan wawancara, baik langsung maupun tidak langsung. Wawancara dilakukan di Padepokan Karakter dengan 5 dosen dan 18 mahasiswa sebagai warga negara muda yang berada di Padepokan Karakter. Penentuan subjek dilakukan secara purposive karena beberapa narasumber dan objek penelitian sudah ditentukan dari awal. Studi dokumentasi dilakukan untuk melihat dokumendokumen yang dimiliki Padepokan Karakter. Sedangkan, observasi dilakukan untuk mengamati pelaksanaan strategi di Padepokan Karakter. Data yang terkumpul kemudian dianalisis secara kualitatif dengan menggunakan model interaktif dari Miles dan Huberman (1994). Langkahlangkah analisis meliputi reduksi data, klarifikasi data, penyajian data, dan pengambilan simpulan.

\section{HASIL DAN PEMBAHASAN Hasil}

Berdasarkan bermacam-macam persoalan karakter warga negara muda, "Padepokan Karakter" di Universitas Negeri Semarang memiliki beberapa strategi untuk mengatasinya. Salah satu strategi yang digunakan yaitu mengembangkan sebuah model pembelajaran yang dapat menguatkan karakter berpikir kritis warga negara muda (mahasiswa). Model pembelajaran ini merupakan bagian dari model yang sedang dikembangkan oleh Padepokan Karakter. Model ini dinamai dengan model pembelajaran berbasis bursa nilai.
Berdasarkan data hasil penelitian
dari observasi, wawancara, dan dokumentasi bahwa pengembangan model pembelajaran bursa nilai di Padepokan Karakter mengambil model yang berlaku dalam masyarakat pasar modal, terutama mengenai cara anggota masyarakat melakukan proses mekanisme sosial melalui serangkaian kesepakatan sosial. Terdapat dua posisi dalam model pembelajaran bursa nila ini yaitu investor sebahai pemilik modal dan emiten sebagai penjual karya sebagai sebuah solusi atau objek yang didiskusikan. Melalui kesepakatan-kesepatan inilah investor dan emiten mempelajari pengetahuan akademis dan mereka melibatkan diri dalam pemecahan masalah krisis nilai-nilai karakter bangsa. Model yang dikembangkan ini memiliki tiga konsep utama yaitu penelitian, pengetahuan, dan dinamika belajar kelompok.

Tahap penelitian dalam model pembelajaran bursa nilai dimaksudkan sebagai proses yang dilakukan dengan tujuan kelompok investor dan kelompok emiten dirangsang dengan cara menghadapkannya pada masalah krisis nilai-nilai karakter. Di dalam proses ini, kedua kelompok memasuki situasi tertentu agar mereka memberikan respons terhadap krisis nilai karakter yang mereka rasakan untuk dipecahkan. Masalah itu sendiri timbul dari Lembaga Penunjang (dosen), dan dari keinginan investor (kelompok pembeli/penanam modal) atau dari emiten (penjual). Untuk memecahkan masalah ini, mereka dituntun untuk mengikuti prosedur dan persyaratan yang sudah ditentukan.

Tahap pengetahuan ialah tahap yang ditandai dengan pengalaman yang tidak dibawa sejak lahir, tetapi diperoleh oleh individu melalui pengalamannya, baik secara langsung maupun tidak langsung. Hal ini didasarkan pada filosofi bahwa pengalaman merupakan guru yang terbaik (Gupta, Ong, \& Feng, 2017; Goodwin, Roegman, \& Reagan, 2016). 
Adapun tahap dinamika kelompok menunjuk pada suasana yang menggambarkan kelompok investor dan kelompok emiten saling berinteraksi mengenai pemecahan masalah krisis nilainilai karakter yang sengaja dilihat atau dikaji bersama. Dalam interaksi ini, terjadi pelibatan proses berbagi ide dan pendapat serta saling tukar pengalaman melalui proses saling berargumentasi terhadap keefektifan, kesederhanaan, kemudahan, dan sifat keterukuran dari model penanggulangan krisis nilai-nilai karakter yang diperjualbelikan. Hal-hal tersebut merupakan dasar dari model bursa nilai. Langkah-langkah dalam model pembelajaran berbasis bursai nilai ini dapat dilihat dalam tabel 1 berikut.

Table. 1 Model Bursa Nilai dalam Padepokan Karakter

\begin{tabular}{|c|c|c|}
\hline \multicolumn{3}{|c|}{ Menumbuhkan Nilai-Nilai Karakter Bangsa } \\
\hline $\begin{array}{l}\text { Kegiatan } \\
\text { Pendidik }\end{array}$ & Langkah pokok & Kegiatan peserta didik \\
\hline 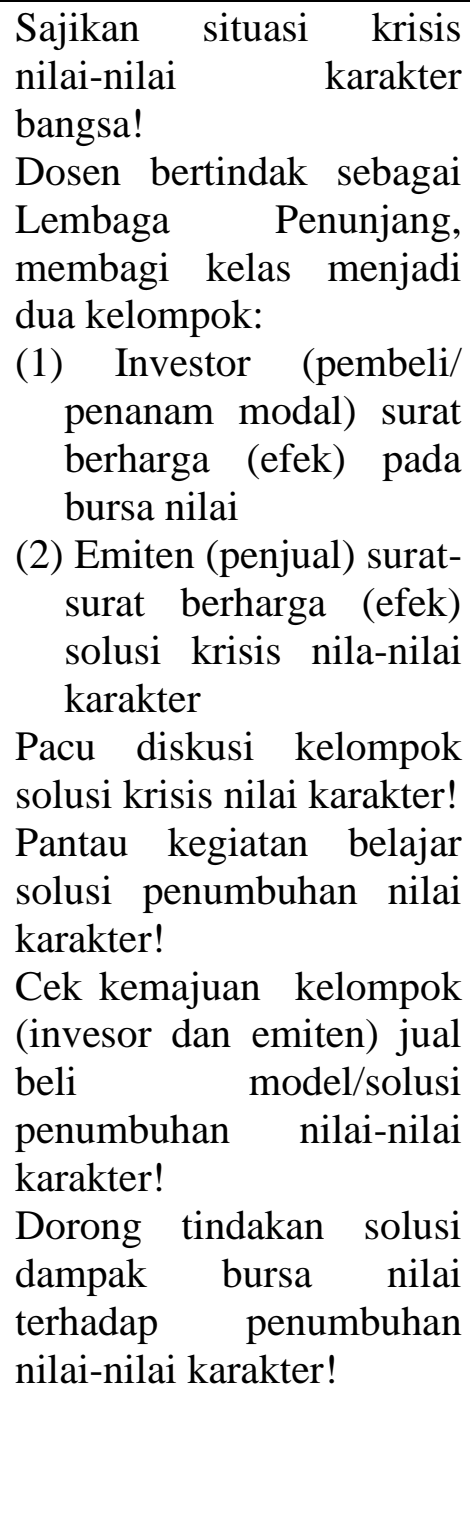 & $\begin{array}{c}\text { Eksplorasi respons } \\
\text { kelnmnnk }\end{array}$ & 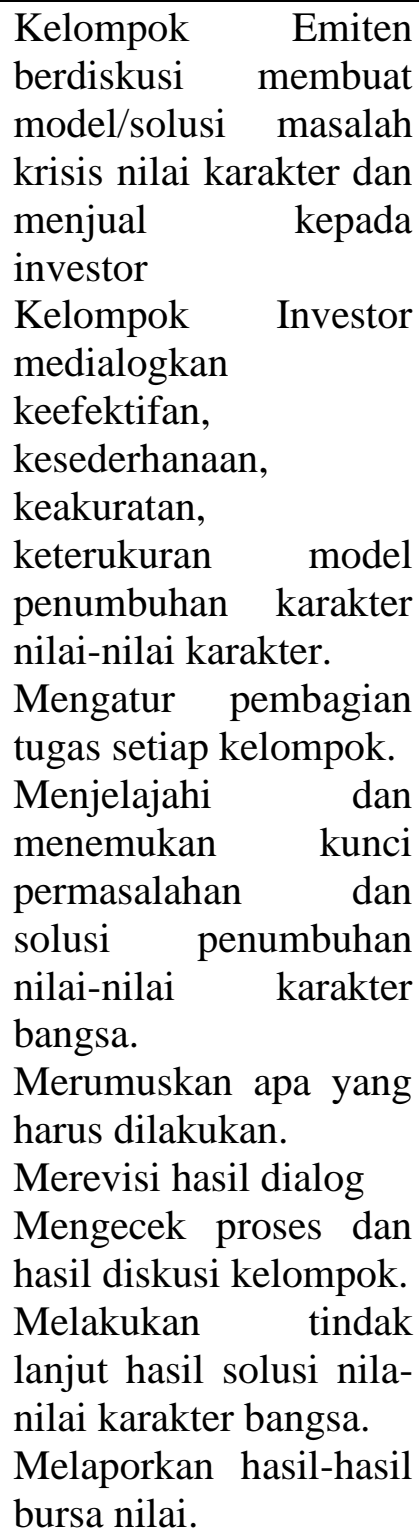 \\
\hline
\end{tabular}

(Sumber: Hasil Penelitian yang merupakan pemikiran Maman Rachman, 2019) 
Berdasarkan tabel Table 1 di atas dapat dijelaskan bahwa langkah-langkah operasional kegiatan dalam model pembelajaran berbasis bursai nilai ini terdiri atas tujuh tahapan, yaitu: (1) menyajikan situasi krisis karakter tanggung jawab dan kejujuran (keilmuan); (2) membagi kelas menjadi dua kelompok yaitu investor dan emiten. Investor dipilih dari mahasiswa. Secara individual investor bertugas membeli surat berharga (efek) sebagai karya berupa solusi atas permasalahan karakter yang dikaji dan penguatan karakter dari emiten sebagai penjual. Tinggi/rendahnya harga efek sangat tergantung kepada keefektifan dan kemanfaatan efek. Modal diperoleh dari lembaga penunjang (dosen). Emiten menjual (efek/karya) sebagai solusi atas krisis karakter kepada investor. Karya atau efek bisa berupa model, cara, strategi, yang bertujuan untuk penguatan karakter akibat persoalan yang dihadapi. Setiap emiten terdiri atas 3 orang. Tawar menawar harga efek sangat tergantung kepada kepiawaian emiten dalam menjelaskan dan keefektifan/kemanfaatan model; (3) memacu diskusi kelompok solusi krisis karakter; (4) mengecek kemajuan kelompok (investor dan emiten) dalam jual beli efek sebagai solusi penguatan karakter; (5) meminta wakil investor mempresentasikan hasil pembelian efek; (6) mengajak para mahasiswa melakukan refleksi meta kognitif solusi penguatan karakter; dan (7) mengakhiri kegiatan bursa nilai dengan kegiatan lelang.

Penerapan model pembelajaran berbasis bursai nilai dilakukan selama 4 (empat) kali pertemuan. Pada pertemuan pertama dan kedua disampaikan kontrak kuliah dan permalasahan yang harus dikritisi oleh mahasiswa serta penjelasan mengenai pelaksanaan model pembelajaran berbasis bursa nilai.

Pertemuan ketiga diawali dengan melakukan presensi dan berdoa. Lalu dilakukan pengecekan tentang penugasan yang telah diberikan kepada mahasiswa pada minggu sebelumnya. Mahasiswa langsung diminta untuk berkumpul pada kelompok yang sudah ditentukan, yaitu kelompok investor (subagen) dan kelompok emiten (penjual). Proses kegiatan tersebut dapat dilihat pada gambar 1 berikut.

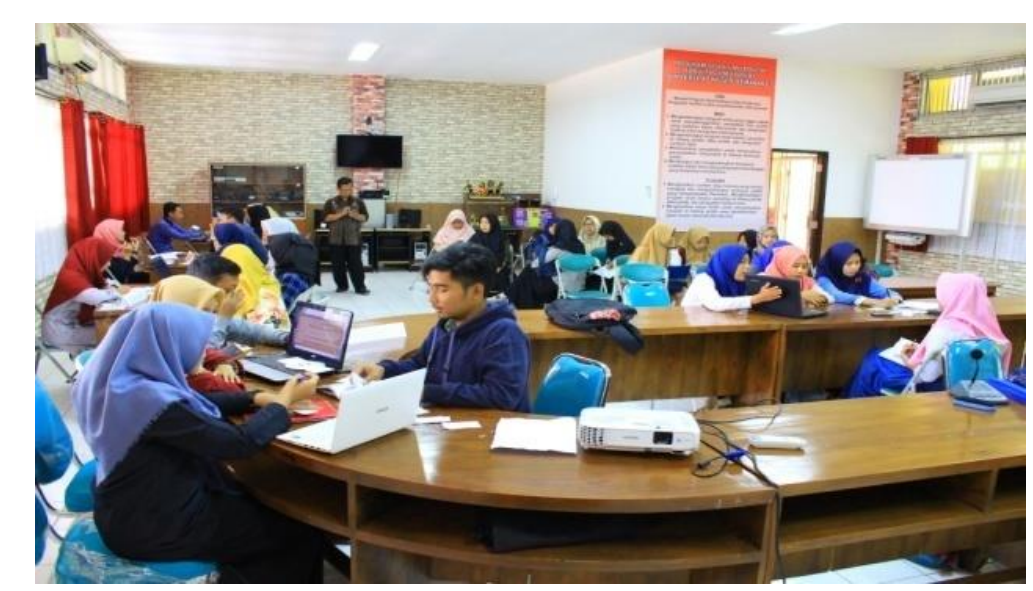

Gambar 1. Pelaksanaan Model Pembelajaran Berbasis Bursa Nilai Padepokan Karakter (Sumber: Dokumentasi Penelitian, 2019) 
Berdasarkan gambar 1 tersebut
terlihat bahwa pelaksanaan penguatan karakter bangsa di Padepokan Karakter dengan model pembelajaran berbasis bursa nilai memiliki kekhasan tersendiri. Mahasiswa yang menjadi penjual berkelompok berjumlah tiga orang berada di luar lingkaran. Sedangkan, mahasiswa yang telah terpilih menjadi pembeli atau investor berada di dalam lingkaran. Pihak investor dan emiten saling berdiskusi dan beradu argumen untuk mempromosikan urgensi inovasi yang dibuat emiten sebagai solusi karakter bangsa yang ditemui. Sedangkan, investor menanyakan kelebihan-kelebihan dari solusi yang ditawarkan untuk bisa dibeli ketika memang sudah mencapai kesepakatan.

Pelaksanaan penguatan

karakter bangsa menggunakan model pembelajaran berbasis bursa nilai di Padepokan Karakter bersifat demokratis. Terdapat sistem sosial yang ditandai oleh keputusankuputusan yang dikembangkan dari investor atas tawaran dari emiten dengan diperkuat pengalaman kelompok dalam konteks masalah yang menjadi titik sentral kegiatan belajar. Kegiatan kelompok emiten dengan investor baik yang pertama sampai dengan yang selanjutnya terjadi secara serempak. Status lembaga penunjang (dosen), investor, dan emiten memiliki kesamaan dalam menghadapi masalah yang dipecahkan dengan peranan yang berbeda. Iklim kelas dalam model pembelajaran berbasis bursai nilai ditandai oleh proses interaksi bersifat kesepakatan atau konsensus antara investor dan emiten dengan pengarahan lembaga penunjang.

Pengarahan yang dilakukan oleh lembaga penunjang (dosen) yaitu untuk melakukan tiga tahap yaitu pemecahan masalah, tahap pengelolaan kelas, dan tahap pemaknaan oleh setiap kelompok. Tahap pemecahan masalah berkenaan dengan masalah krisis nilai-nilai karakter, apa yang menjadi hakikat masalah krisis karakter, dan apa yang menjadi fokus masalah krisis niai. Tahap pengeloaan kelas berkenaan dengan proses jual/beli model cara memecahkan masalah krisis nilai karakter, informasi apa saja yang diperlukan, bagaimana mengorganisasikan kelompok untuk memperoleh informasi itu. Sedangkan tahap pemaknaan kelompok berkenaan dengan proses pengkajian bagaimana kelompok/seseorang menghayati dampak dari proses mengikuti model pembelajaran berbasis bursa nilai.

Berdasarkan gambar 1 terlihat juga bahwa ada dampak pengiring yang muncul, yaitu: (1) karakter demokratis dan komitmen terhadap nasionalisme, (2) kepedulian dan kepatuhan pada aturan sosial, (3) kecerdasan dan kejujuran dalam kebersamaan, dan (4) berpikir logis, kritis, kreatif, dan inovatif dalam pemecahan masalah.

Berpikir kritis warga negara muda ditunjukkan oleh cara berpikir mahasiswa dan bagaimana dia melaksanakan sesuatu secara logis untuk menghasilkan cara atau temuan baru yang mutakhir terhadap yang telah ada atau telah dimilikinya. Para mahasiswa dalam berdialog dan berinteraksi jual beli model pemecahan krisis karakter dilakukan 
dengan memperhatikan kelogisan dan kebaruan, sehingga berpikir kritis menimbulkan munculnya kreativitas di kalangan anggota kelompok, baik emiten maupun investor.

Setelah mengikuti pembelajaran dengan model berbasis bursa nilai di Padepokan Karakter, mahasiswa sebagai warga negara muda diberikan refleksi sebagai bentuk upaya pengukuran model pembelajaran berbasis bursa nilai yang dikembangakan di Padepokan Karakter. Refleksi ini berupa pesan dan kesan secara tertulis, pengungkapan sikap terhadap pembelajaran, dan komentar tentang nilai karakter apa yang dirasakan dan dilakukan ketika pembelajaran berlangsung. Hadiah atau reward diberikan dalam bentuk lelang di akhir pembelajaran.

\section{Pembahasan}

Berdasarkan hasil penelitian, didapatkan beberapa aktivitas akibat inovasi yang dilakukan oleh Universitas Negeri Semarang. Inovasi yang dimaksud adalah Padepokan Karakter sebagai wadah baru penguatan karakter bagi para mahasiswa supaya menjadi lulusan yang berkarakter Indonesia. Wadah inilah yang disebut sebagai komunitas berkarakter. Terkait dengan hal ini Primasari (2019: 1114) berpendapat bahwa pembentukan karakter memerlukan communities of character. Keberadaan komunitas inilah yang berkontribusi dalam memberikan keteladanan, mengintervensi nilai kebaikan, serta adanya pembiasaan yang harus dilakukan secara konsisten dan saling menguatkan satu sama lain.
Salah satu strategi Padepokan Karakter untuk penguatan karakter bagi mahasiswa yaitu membuat model pembelajaran berbasis bursa nilai. Model baru ini membawa dampak positif bagi warga negara muda untuk memiliki kemampuan berpikir kritis yang logis dan reflektif. Karakter berpikir kritis harus ditumbuhkan sejak dini di sekolah hingga di perguruan tinggi. Bagi mahasiswa berpikir kritis merupakan modal untuk kesuksesannya dalam kuliah di era global sekarang ini (Khalistiyawati \& Muhyadi, 2018; Haryadi, 2017).

Pelaksanaan model pembelajaran berbasis bursa nilai diawali dengan pemberian tugas kepada mahasiswa untuk mencari krisis karakter yang melanda pemuda Indonesia. Pencarian dilakukan menggunakan alat teknologi modern seperti internet. Hal ini melengkapi kemampuan mahasiswa sebagai warga negara muda untuk menguasai teknologi modern di abad 21. Selain itu, aktivitas mencari dan menganalisis suatu masalah atau kasus memicu rasa ingin tahu mahasiswa untuk mengetahui sebuah kasus tentang krisis karakter. Seperti yang dikatakan oleh Wilson (2016) bahwa berpikir kritis berhubungan dengan refleksi diri yang didalamnya terdapat rasa ingin tahu yang tinggi. Inti dari berpikir kritis adalah keterampilan untuk melakukan interpretasi, analisis, evaluasi, dan mengambil simpulan dengan tujuan akhir berupa penjelasan (Facione, 1990).

Dalam aktivitas memaknai informasi yang didapatkan juga terdapat aktivitas mendiskusikan dengan teman sebaya untuk mencari 
solusi terbaik atas persoalan yang dikaji. Aktivitas ini melahirkan cara pikir secara kognitif dari mahasiswa untuk mencari dasar dalam memaknai dan memberikan solusi atas persoalan yang dikaji. Miller et al. (Peverill, Garon, Brown, \& Moore, 2017) menjelaskan bahwa berpikir kritis memerlukan penerapan yang dibarengi tujuan untuk melatih kemampuan kognitif dan kebiasaan. Kemampuan kognitif merupakan kemampuan utama yang mendasari bagaimana karakter yang diinginkan muncul pada mahasiswa. Hal ini merupakan dasar yang dapat mempengaruhi bagaimana perasaan dan tindakan muncul dari setiap manusia. Tataran teoretis ini disebut sebagai moral knowledge, moral feeling, dan moral action.

Mencari, memaknai, dan menilai sebagai langkah awal dalam model pembelajaran berbasis bursa nilai disebut sebagai kegiatan penelitian dan pengetahuan. Selannjutnya, emiten (penjual) sebagai kelompok yang memiliki solusi berupa "surat efek" menjual hasil dari kerja kelompok kepada investor sebagai pembeli atau pemodal. Di sini terjadi aktivitas yang disebut sebagai dinamika kelompok.

Dinamika

kelompok

membutuhkan sebuah ide cemerlang untuk menawarkan produk emiten sebagai solusi sebuah persoalan krisis karakter. Tahap ini membutuhkan upaya persuasif untuk mempengaruhi investor supaya dapat membeli produk atau surat efek sebagai solusi persoalan yang dikaji. Terjadi aktivitas konstruksi persoalan yang sulit dipahami, untuk didefinisikan dan dipahami dari studi lapangan (Wade, 1995). Aktivitas ini merupakan berpikir kritis yang dipahami sebagai keterampilan dan disposisi (Buckley, Archibald, Hargraves, \& Trochim, 2015). Aktivitas ini juga melibatkan seperangkat kapasistas yang termasuk di dalamnya kegiatan menafsirkan, memprediksi, menganalisis, dan mengevalusi (Carmel \& Yezierski, 2013: 78). Inverstor mengevaluasi pada apa yang ditawarkan oleh kelompok emiten terkait "surat efek" yang ditawarkan sebagai solusi persoalan krisis karakter.

Tawar menawar antara emiten sebagai penjual dan investor sebagai pembeli dibarengi argumen yang kuat dari keduanya. Argumen ini bagi emiten digunakan untuk beretorika agar investor dapat membeli produknya sebagai tanda keberhasilan produk yang dibuat. Aktivitas ini merupakan aktivitas mahasiswa yang memiliki pemahaman yang mendalam tentang produk dan persoalan yang dikaji sehingga dapat dipromosikan dengan baik. Hal ini sesuai dengan pendapat Kallet (2014: 3) bahwa individu yang kritis memiliki pemahaman yang mendalam tentang suatu yang dikaji.

Aktivitas belajar ditutup dengan kegiatan lelang sebagai bentuk reward. Aktivitas ini merupakan aktivitas penutup dari kegiatan pembelajaran yang menggunakan model pembelajaran berbasis bursa nilai. Dengan demikian, aktitvitas mahasiswa dalam pembelajaran berbasis bursa nilai didapati aktivitas menginterpretasi sebuah isu dan persoalan krisis karakter, menganalisis persoalan tersebut 
untuk diberikan penilaian tertentu. Dari penilaian itu, disimpulkan inti dari persoalan untuk dicarikan solusi. Pada tahap akhir dijelaskan kepada investor gagasan solutif atau "surat efek" untuk dijual sebagai bentuk keberhasilan kerja kelompok emiten. Hal ini secara pelan-pelan mengajarkan kepada mahasiswa cara pikir kritis yang akhirnya mengakar bersama karakter masing-masing.

Kegiatan penutup dari model pembelajaran berbasis bursa nilai adalah kegiatan lelang. Kegiatan ini sebagai upacaya memberikan apresiasi kepada mahasiswa untuk merangsang pengetahuan dan perasaannya. Hal ini sesuai dengan yang dikatakan Kristin, Maya, \& Evy (2016) bahwa hadiah menjadi faktor yang mempengaruhi kesadaran sebagai manajemen pengetahuan.

Aktivitas pembelajaran dengan model ini memenuhi beberapa langkah dalam berpikir kritis. Sintaks yang menjadi indikator berpikir kritis adalah andanya interpretasi, analisis, evaluasi, pengambilan simpulan, dan sebuah penjelasan secara utuh (Anderson \& Krathwohl, 2001).

\section{PENUTUP}

Abad 21 ditandai dengan berbagai kemajuan teknologi informasi menuntut setiap negara untuk mengikutinya supaya tidak tertinggal dengan menyiapakn sumber daya manusia yang mumpuni. Sumber daya yang mumpuni memerlukan pendidikan yang berkualitas. Salah satu caranya melalui lembaga pendidikan yang mampu menjadi wahana yang strategis untuk mengembangkan karakter. Diperlukan proses pendidikan yang berpihak kepada pengembangan karakter generasi muda. Generasi muda yang memiliki karakter baik akan mampu menyikapi, dan menjalani kehidupan dari tantangan yang berat.

Hal inilah yang menjadikan alasan lembaga pendidikan memperkuat pendidikan karakter, seperti yang dilakukan Universitas Negeri Semarang dengan membetuk Padepokan Karakter untuk mengembangkan karakter mahasiswa yang mampu berpikir kritis. Metode yang dikembangkan dengan model pembelajaran berbasis bursa nilai. Pembelajaran diawali dengan mencari berita kasus yang berkaitan dengan karakter melalui teknologi informasi yang dimiliki mahasiswa, kemudian menganalisis kasus tersebut dan memberikan solusi alternatif melalui diskusi kelompok. Selanjutnya solusi yang ditawarkan tersebut akan ditawarkan pada invertor sebagai penilai tentang layak atau tidaknya gagasan yang ditawarkan. Apabila dianggap layak dan baik maka akan dilakukan lelang untuk menjual gagasan tersebut. Proses lelang ini mampu menunujkkan bahwa gagasan yang ditawarkan dapat diterima dan dapat diterapkan untuk menyelesaikan masalah yang ada.

\section{UCAPAN TERIMA KASIH}

Penulis bersyukur kepada Allah Swt. atas dimuatnya tulisan ini yang prosesnya cukup panjang mulai dari penelitian hingga terselesaikannya penulisan ini. Penulis mengucapkan terima kasih kepada semua dosen di prodi PPKn Program Pascasarjana Universitas Negeri Yogyakarta yang telah banyak memberikan ilmu yang 
berharga. Ucapan terima kasih juga disampaikan kepada dewan redaksi Jurnal Pendidikan Karakter yang bersedia menerbitkan tulisan ini.

\section{DAFTAR PUSTAKA}

Abidin, Z. (2000). Filsafat manusia: Memahami manusia melalui filsafat. Bandung: PT Remaja Rosda Karya.

Anderson, L.W. \& Krathwohl, D.R. (2001). A Taxonomy for learning, teaching, and assesing: A revision of Bloom's taxonomy of educatioanl objectives. New York: Addison Wesley Longman, Inc.

Banks, J. A. (2008). Diversity, group identity, and citizenship education in a global age. Educational Researcher, 37(3), 129-139.

DOI: 10.3102/0013189X08317501.

Buckley, J., Archibald, T., Hargraves, M., \& Trochim, W. M. (2015). Defining and teaching evaluative thinking. Insights From Research on Critical Thinking, 36 (3), 375388.

DOI: $\underline{10.1177 / 1098214015581706 .}$.

Budiwibowo, S. (2013). Membangun pendidikan karakter generasi muda melalui budaya kearifan lokal di era global. Premiere Education, Jurnal Pendidikan Dasar dan Pembelajaran, 3(1), 39-49.

DOI: 10.25273/pe.v3i01.57.

Carmel, J., \& Yezierski, J. E. (2013). Are we keeping the promise? Investigation of students' critical thinking growth. Journal of College Science Teaching, 42 (5), 71-78. Retrieved from https://www.jstor.org/stable/43 631585\#metadata_info_tab_co ntents.

Creswell. J.W. (1998). Qualitative inquiry and research design: Choosing amongfive tradition. London: Sage Publication.

Detik.com. (2011). 39\% ABG di kota besar Indonesia sudah pernah hubungan seks. Retrieved from https://health.detik.com/anakdan-remaja/d-1782962/39-abgdi-kota-besar-indonesia-sudahpernah-hubungan-seks.

Facione, P. A. (1990). The California critical thinking skills testcollege level. technical report2. Factors predictive of CT skills. American Philosophical Association (pp. 1-21). La Cruz Millbrae. Retrieved from https://eric.ed.gov/?id=ED3275 $\underline{50 .}$

Goodwin, A. L., Roegman, R., \& Reagan, E. M. (2016). Is experience the best teacher? Extensive clinical practice and mentor teachers' perspectives on effective teaching. Urban Education, 51(10), 1198-1225. DOI: 10.1177/0042085915618720.

Gupta, A., Ong, Y. S., \& Feng, L. (2017). Insights on transfer optimization: Because experience is the best teacher. IEEE Transactions on Emerging Topics in Computational Intelligence, 2(1), 51-64. DOI: $10.1109 /$ TETCI.2017.27 69104.
Haryadi,
$D$. (2017). Menumbuhkan karakter akademik dalam perkuliahan berbasis logika. Jurnal Pendidikan Karakter, 7(1), 
1-13.

10.21831/jpk.v7i1.15491.

Kallet, M. (2014). Think smarter critical thinking to improve problem-solving and decisionmaking skills. Canada: John Wiley \& Sons.

Khalistiyawati, M. \& Muhyadi. (2018). Pengaruh model STAD dan jigsaw terhadap karakter kerja sama, kemampuan berpikir kritis, dan hasil belajar kognitif. Jurnal Pendidikan Karakter, 8(2), 1-13. DOI: 10.21831/jpk.v8i2.21852.

Kristin, D. Maya., \& Evy. (2016). Knowledge management system evaluation. Pertanika Journal of Social Sciences \& Humanities, JSSH, 24(S, July), 1-7. Retrieved from http://www.pertanika.upm.edu. my/Pertanika\%20PAPERS/JSS H\%20Vol.\%2024\%20(S)\%20J ul.\%202016\%20(View\%20Full \%20Journal).pdf.

Lalo, K. (2018). Menciptakan generasi milenial berkarakter dengan pendidikan karakter guna menyongsong era globalisasi. Jurnal Ilmu Kepolisian, 12(2), 68-75. Retrieved from http://www.jurnalptik.id/index. $\mathrm{php} / \mathrm{JIK} /$ article/view/23/19.

Miles, M. B., \& Huberman, M. A. (1994). Qualitative data analysis: An expanded sourcebook (2rd ed). London: Sage Publication.

Peverill, S., Garon, N., Brown, A., \& Moore, C. (2017). Depleting and motivating self-regulation in preschoolers. Cognitive Development, 44(October),
116-126. DOI: 10.1016/j.cogdev.2017.09.005. Philips, M. M. (2010). A colorful, costly dogfight takes shape in house race. The Wall Street Journal, October 12, 2010. Accessed on May 1, 2019, from

https://www.wsj.com/articles/S B100014240527487039275045 75540330106432228 .

Primasari, D.A.G, dkk. (2019). Pendidikan karakter bagi generasi masa kini. Prosiding Seminar Nasional Pendidikan Program Pascasarjana Universitas PGRI Palembang, 12 Januari 2019, 1100-1118.

Putri, R. D., \& Ramadhani, E. (2018). Pendidikan karakter cerdas format kelompok (PKCKO) dalam membentuk karakter penerus bangsa. Prosiding Seminar Nasional Pendidikan PGRI 2017, "Pengembangan Pendidikan Karakter untuk Meningkatkan Marwah Bangsa," 27 April 2017, 469472. Retrieved from https://jurnal.univpgripalembang.ac.id/index.php/pro siding/article/view/1490/1300.

Setiawati, N.A. (2017). Pendidikan Karakter sebagai pilar pembentukan karakter bangsa. Prosiding Seminar Nasional Tahunan Fakultas Ilmu Sosial Universitas Negeri Medan Tahun 2017, 1(1), 348-352.

Subekti, H. (2009). Upaya membangun generasi berkarakter bangsa melalui kebiasaan berpikir sukses. Jurnal Didaktis, 8(3), 34-42. Retrieved from 
file:///C:/Users/UNY/Downloa ds/247-675-1-PB.pdf.

Trilling, B. \& Fadel, C. (2009). 21 Century skills: Learning for live on our times. United State of America: Jossey-Bass.

Wade, C. (1995). Using writing to develop and assess critical thinking. Teaching of Psychology,
22(1), 24-28. DOI:

10.1207/s15328023top2201_8.

Wilson, K. (2016). Critical reading, critical thinking: Delicate scaffolding in English for Academic Purposes (EAP). Thinking Skills and Creativity, 22(December), 256-265. DOI: 10.1016/j.tsc.2016.10.002. 